\title{
Silent Accord: $Q i$ 契 as a Metaphor for Enlightenment and Transmission in Chan Buddhist Discourse
}

\author{
Aleksi Järvelä ${ }^{1, *}$ and Tero Tähtinen ${ }^{2}$ (D) \\ 1 University of Helsinki, 00014 Helsinki, Finland \\ 2 Tampere University, 33100 Tampere, Finland; tero.tahtinen@tuni.fi \\ * Correspondence: aleksi.jarvela@helsinki.fi
}

\section{check for}

updates

Citation: Järvelä, Aleksi, and Tero Tähtinen. 2021. Silent Accord: $Q i$ 契 as a Metaphor for Enlightenment and Transmission in Chan Buddhist Discourse. Religions 12: 279.

https: / / doi.org/10.3390/ rel12040279

Academic Editor: George Wrisley

Received: 19 February 2021

Accepted: 12 April 2021

Published: 16 April 2021

Publisher's Note: MDPI stays neutral with regard to jurisdictional claims in published maps and institutional affiliations.

Copyright: (c) 2021 by the authors. Licensee MDPI, Basel, Switzerland. This article is an open access article distributed under the terms and conditions of the Creative Commons Attribution (CC BY) license (https:// creativecommons.org/licenses/by/ $4.0 /)$.

\begin{abstract}
In this paper, we explore the historical background and the semantic underpinnings of a central, if marginally treated, metaphor of enlightenment and transmission in Chan discourse, “silent accord" 默契. It features centrally in Essentials of the Transmission of Mind 傳心法要, a text that gathers the teachings of Chan master Huangbo Xiyun (d. ca. 850), a major Tang dynasty figure. "Silent accord" is related to the concept of mind-to-mind transmission, which lies at the very core of Chan Buddhist self-understanding. However, Chan historiography has shown that this selfunderstanding was partially a product of the Song dynasty lineage records, historically retroactive syncretic constructs produced by monks and literati as efforts towards doctrinal and political recognition and orthodoxy. There are thus lacunae in the history of Chan thought opened up by the retrospective fictions of Song dynasty, and a lack of reliable, dateable documents from the preceding Tang dynasty era, possibly fraught with later additions. We situate the metaphor "silent accord" in the history of Chan thought by searching for its origins, mapping its functions in Chan literature, arguing for its influence and thereby its role in helping to bridge the ninth century gap.
\end{abstract}

Keywords: Chan (Zen) Buddhism; transmission; enlightenment; Huangbo Xiyun; Pei Xiu; silent accord

\section{Introduction: Holding the Line, Bridging the Gap}

We examine the role, function, and influence of the metaphor of "silent accord" 默契 in the development of Chan thought, especially during what is termed the middle period of Chan (750-1000), covering roughly the most part of Tang dynasty (618907) and the subsequent Five Dynasties and Ten Kingdoms era (907-979), ending in the early part of Song dynasty (960-1279). What makes this period difficult to research with historical accuracy, is a lack of reliable, dateable texts.

By the end of the Chan tradition ${ }^{1}$ ascendancy ${ }^{2}$ during the Song dynasty (9601279), it had formulated of itself a consistent definition, a coherent self-image. At its center are the well-known quintessential four slogans ${ }^{3}$

$\begin{array}{ll}\text { Separate transmission outside the teachings， } & \text { 教外别傳 } \\ \text { not established on words and letters， } & \text { 不立文字 } \\ \text { directly pointing to the human mind, } & \text { 直指人心 }\end{array}$

1 For discussion whether to translate 宗 zong as “school”, “tradition”, “orthodoxy”, or “lineage”, see e.g., (Tang 1963, pp. 1-18), (Mano 1964, pp. 234-96), (Weinstein 1987, pp. 482-87), (Foulk 1992, pp. 18-31), (Welter 2004, pp. 461-65). For a convenient summary, see (Jia 2006, pp. 1-2). In this article, we use "orthodoxy" to refer to the Song dynasty matured version of self-image propagated by the four slogans. We use "lineage" more widely, to refer to different historical lineages within and without the "orthodoxy", as well as methodologically, referring to the abstract idea of "lineage" that takes different forms produced in various lineage documents. Thus, "lineage document" here means loosely any Chan document that has lineage building and/or transmission affect the form of the work. Works such as Faith in Mind Inscription 信心銘 Xinxinming or Shitou's Inquiry into Matching Halves 參同契 Cantongqi do not count, but Record of the Baolin Monastery 寶林傳 Baolin zhuan (801) and Collection of the Patriarchal Hall 祖堂集 Zutangji (952) do. Essentials of the Transmission of Mind 傳心法要 Chuanxin fayao is a record of Huangbo's teachings and not a lineage text in itself.

2 Political, cultural, and spiritual hegemony. For relations between Chan and the Song state see (Schlütter 2008, pp. 31-55), for detailed analysis of lineage documents, power relations and imperial sanction see (Welter 2006).

3 This set was not complete until the Song dynasty, appearing in the Colletion of Topics From the Garden of the Patriarchs 祖庭事苑 Zuting shiyuan, compiled by Muan Shanqing 睦庵善卿 in 1108. For a more detailed study of the four slogans and other staple phrases, see (Welter 2000, pp. 75-109). 


\section{seeing one's nature and becoming a Buddha. 見性成佛}

This self-image was based on an understanding of its own history that has been shown to be rife with retroactive fabrications, and a considerable part of the study of Chan is the study of how, when and why these fictions and fabrications came to be (Yampolsky 1967), (Lai and Lancaster 1983), (Broughton 1999), (Heine and Wright 2000), (McRae 2003), (Jia 2006). However, while much of the narratives of such key concepts as lineage, legitimacy, orthodoxy and transmission, around which these four phrases were formulated, are made of the stuff of myth, they are no less central by fact of their fictionality. ${ }^{4}$ For they are the concepts through which the questions regarding enlightenment, its doctrinal basis, and practices of acquisition and propagation, were negotiated.

Essentials of the Transmission of Mind 傳心法要 Chuanxin fayao (hereafter Essentials), a text recording the teachings of Huangbo Xiyun 黃檗希運 (d. ca. 850) presents an interesting study. According to the text's preface (857), Huangbo's teachings were written down by Pei Xiu 裴休 (787 or 797-860), both an eminent politician and a serious Buddhist scholar and practitioner. In the year 821, Pei received a government assignment in the southern Jiangxi province and came into contact with the famous Chan master Huangbo living in the area. According to his own account, year 842 Pei invited master Huangbo to teach Dharma in Longxing temple and questioned him tirelessly about the Dharma. Later on, Pei Xiu compiled their dialogues to two texts titled ${ }^{5}$ Essentials and Wanling Record 宛陵錄6 (Wright 2004, pp. 109-10).

In Essentials, Huangbo establishes what he terms "silent accord" 默契. This concept embodies his way of addressing the question of enlightenment and transmission in light of the problem of language as a vehicle of truth.

As was suggested by the first slogan 教外別傳, sidestepping for the moment the question of separateness, ${ }^{7}$ the action of transmission (傳) lies at the core of the Chan worldview. According to the slogans, supposedly unlike the more textually and scholarly oriented Buddhist schools, Chan prided itself as a lineage that transmitted the Buddhadharma without depending on scriptures or other external forms, but directly and intimately from mind to mind. When a Chan master recognized that a student had reached an equal state of enlightenment and granted him a Dharma transmission, the student became a member of the Chan lineage, which traced its roots back to historical Shakyamuni Buddha. In essence, this means that the receiver of Dharma transmission was seen as a living Buddha (Schlütter 2007, p. 381). ${ }^{8}$

That transmission from mind-to-mind was essential, as from the very beginning, Chan rhetoric was bound by the Mahāyāna concept of śūnyat - the emptiness of all things. As nothing has self-nature, even the truth of enlightenment cannot be a thing. Therefore, what is transmitted through the lineage cannot be any-thing either, because what is transmitted is no-thing. As no-thing-ness cannot be exhaustively verbalized, language becomes problematic. Transmission and lineage, then, became important as enlightenment became increasingly difficult to doctrinally debate. The problem that might seem negligible from the point of view of meditation praxis, was vexing from the point of view of establishing an independent tradition and producing the requisite documents for it.

These problematic conditions led in the end to the lineage-based orthodoxy that reached its mature form during the Song dynasty. The resolution was built on what McRae calls the "genealogical model", a perpetual familial system that is based on organizing lineages through which enlightenment, the ultimate meaning of Buddhism

\footnotetext{
The first of McRae's rules of Zen study is "It's not true, and therefore it's more important." (McRae 2003, p. xix).

The titles are probably given later and taken from Pei Xiu's preface.

(T.2012A) and (T.2012B) Wanling Record has more issues regarding later additions, so we are dealing mostly with the text of Essentials.

This last addition to the set of slogans was a point of contention because of its argument of being separate rather than harmonious with other teachings and was by no means readily accepted (Welter 2000, pp. 81-94).

8 Also, (Buckelew 2019) has argued that the transmission of orthodoxy is not the same thing as transmitting Buddhahood.
} 
itself, is transmitted down generationally, from master to student (McRae 2003, pp. 7-8). This genealogical model took form in and as historical Chan lineage based documents and literary genres such as "flame histories" 燈史 (dengshi). These documents recorded the biographies, teachings, sayings and dialogues of Chan masters, and organized them according to lineage affiliation and in descending generational order, like a family tree. Central to these texts, and other related text genres such as "recorded sayings" 語録 (yulu), was what are often termed "encounter dialogues", records of exemplary dialogues where enlightenment is transmitted.

It is in these documents that portray, debate, and perpetuate lineages of transmission, where the big historiographical discrepancy of Chan is found. Following the simplified phase-chart of Chan history periodization ${ }^{9}$ (McRae 2003, p. 13), the orthodoxy of the Chan slogans takes place halfway through the Song dynasty Chan phase (950-1300).

The discrepancy between the Song dynasty version of Chan history and the documents of the early Chan (600-900) phase found in Dunhuang at the turn of the 20th century present a clear epistemic and textual gap. The documents that supposedly detail the histories and records of middle Chan (750-1000) period, are either written, rewritten or edited during the Song dynasty period. The scarcity of reliable documents from middle Chan period makes its actual history most difficult to accurately and reliably construe. An inevitable result of the gap in dateable documents is that, while the middle Chan period seems to produce many of the ideas found in the Song dynasty Chan orthodoxy in some precursory form, separating original and additional layers of texts is often inconclusive.

The text of Essentials, along with it its portrayal of the "silent accord" is situated in the gap of the middle Chan period. While the text has supposedly been in circulation since 857, the first extant public version of the text can be traced to its inclusion in the second flame history Tiansheng guangdeng $l u$ 天聖廣燈録 (1036) and subsequently added to a later edition of the first flame history Jingde chuandeng lu 景徳傳燈録 (1004) in 1048. However, we consider Huangbo's metaphor central to the development of the Hongzhou 洪州 School, and if not a conceptual forerunner, at least an impetus in the development of the "encounter dialogue": the sine qua non of the matured genealogical model. Essentials seemingly even connects "silent accord" with precursory forms of the four slogans, although this may be a later addition.

Therefore, we trace the outlines of metaphor and its connotations with two aims. One is the historically linear life and development of the metaphor of the character $q i$. We will go through the historical background taking apart its root metaphors in early Chinese literature, and trace its entrance into Chan rhetoric. We compare texts on the cusp of the middle Chan period with Huangbo, in order to map the nature and role of the metaphor. Secondly, we investigate the metaphor's meaning and influence in Chan thought after Huangbo and its potential to function as one stepping-stone over the lacuna of middle Chan textual history.

\section{Etymology and Metaphor of $Q i$ 契}

The Chinese character 契 $q i$ has an old variant 栔 that consists of three parts: 丰 (probably depicting carved lines on a surface), 刀 (dao, “a knife") and 木 ( $m u$, “a tree"). Hence, the dictionary Shuowen jiezi 說文解字 gives the variant 栔 a straightforward and concrete meaning: "to carve" (刻) ke (SWJZ, 251). This can be seen for instance in a proverb 契船求劍 (qichuan qiujian) "to carve a mark on the boat in order to find the sword", which derives from a well-known allegory from the Lüshi Chunqiu 呂氏春秋:

The periodization follows a logic produced by the retroactive view of history, and groups into any one period all things paradigmatic of its time. A new shift in a paradigm begins a new period even if the previous has not run its full course, e.g., the Hongzhou School of Mazu, its new concepts, styles of dialogue, texts, and geographical area of activity separate it from the early period, although they partially overlap in time. 
A man from the state of Chu was crossing a river in a boat when he happened to drop his sword into the water. Hastily, he carved a mark on the side of the boat and told himself: "This is the place where my sword fell." When the boat finally stopped, he dived into the water next to the place pointed by the mark in order to seek for his sword.

楚人有涉江者, 其劍自舟中墜於水, 遽契其舟曰:「是吾劍之所從墜。」舟止, 從其所契者入水求之。(Ctext, 察今)

Here 契 is a verb meaning “to carve" and a part of a sentence "to carve a mark on the side of the boat", using some kind of a pocketknife that a person can carry with oneself. It is also repeated in the last sentence as a part of a grammatical compound 所契者, which makes it a noun phrase, meaning “the place of carving" or simply “a carved mark".

Originally, this idea of carving was closely related to carving of the so-called oracle bones, i.e., pieces of ox scapula or turtle plastron, which were used as tools for ancient Chinese divination, mainly during the Shang dynasty 商朝 (around 16001046 BCE). The remnants of this practice can be seen in the 3rd text of a poem cycle “Mian” 緜 in the Daya 大雅 section of the Shijing 詩經:

The plains of Zhou are lush and luxuriant,

even violets and sowthistles are sweet as syrup.

So he started and laid out plans,

carved his questions to my tortoise shell.

It told which place was suitable for stopping,

and thus he build his house there.

周原膴膴

董茶如飴

爰始爰謀

爰契我龜

曰止曰時

築室于茲

(SJDB, 766)

The poems of both Xiaoya 小雅 and Daya sections of Shijing consist mainly of courtly panegyrics and dynastic hymns that praise the worthy founders of the Zhou dynasty. Unsurprisingly, this poem begins with a praise of the pastoral delights of the fertile Zhou plains into which a human figure appears. In order to receive instructions, he consults the spirits by carving his question on a tortoise shell, which was then heated up. Finally, the surface of the bone cracked, and he (or most probably his priests) was able to read the answers from their labyrinthine crevices. In this poem, the spirits instruct him to settle down in the Zhou plains and that becomes the location of his-and implicitly also his people's-dwelling.

In both of these examples, the character 契 refers to the act of carving on a very concrete level. However, in other occasions, its meaning becomes more abstract and metaphorical; thus, Shuowen jiezi gives 契 a meaning “(great) agreement"(大約) dayue (SWJZ, 592). This usage can be seen for instance in the terse and enigmatic 79th chapter of Daodejing 道德經 in which it is used in two different places but with similar meaning:

Even after calming down a great anger, some remnants of it still remain. How can this be goodness? Therefore, a sage keeps his part of the deal but does not demand payback from others. Those with virtue concern themselves with the deal. Those without virtue concern themselves with the 
debts. The Way of Heaven has no favorites; it always sides with the good ones.

和大怨, 必有餘怨; 安可以為善? 是以聖人執左契, 而不責於人。有德司契, 無德司徹。天道無親, 常與善人。(Ctext, 《道德經》)

The short chapter talks about making deals and how to approach the demands and situations related to them. In ancient China, it was customary to use carved, twopart tallies as a sign of an agreement or a loan. Each side got one part of the tally and, thus, neither side was unable to claim that the deal has been fulfilled or the loan repaid without having both parts of the tally (Chen 2016, p. 342, n. 2). ${ }^{10}$

So, here, the compound 左契 should actually be translated as the "left part of the tally" or, as John Minford (2019, p. 298) does, "left-hand Tally". The left side of the tally was traditionally reserved for the creditor and the right side for the debtor (ibid., p. 299). The character is repeated in a sequence 有德司契, 無德司徹, which, according to Chen (2016, p. 343), should be understood as two similes: those with virtue are broad-minded like those who have many (left-hand) tallies and those without virtue are harsh like tax-collectors. ${ }^{11}$ So, in Chen's interpretation, the tally 契 becomes a metaphor for virtue 德. And those with virtue resemble people who possess several left-hand tallies - an image that alludes to generosity and self-sufficiency.

Nevertheless, the essential point of the quotation is that 契 refers to a two-part deal-making device which also has an abstract meaning, "to agree". This leads to an even more far-stretched and wide meaning, seen in the finale of Tao Yuanming's 陶 淵明 (365?-427) “Peach Blossom Spring” 桃花源記:

I wish to ask the ordinary people of this world,

how do you survey the things beyond clamour and dust?

I myself wish to rise up to the sky with a light wind,

and soar high searching for kindred spirits.

借問遊方士

焉測塵器外

願言躡清風

高舉尋吾契

(TYMJ, 345)

The "Peach Blossom Spring" is the most famous Chinese utopian text describing an ideal community living in paradisiacal harmony with nature unaware of the outside world. The text ends with a verse-form poem which praises the famous historical Chinese recluses and juxtaposes the fictional community with them. In doing so, the poem celebrates the idealized, natural way of living that lacks both king's taxes and recorded calendars. In the last verses, the speaker-who has, by chance, visited the idyllic community-shows his disdain for the mundane world and his wish to (re)unite with the humble rustics living in the hidden seclusion.

He imagines himself in the form of a bird riding the wind and soaring high in the sky. The very last part of the poem 尋吾契 shows yet another way of using 契. According to Wen Hongqian's explanation, in this context, 吾契 should be understood as “people with whom I share the same aspirations" (與我志趣相同的人) and 契 simply as “to unite” (合) he (TYMJ, 346, n. 47). A. R. Davis (2009, p. 197) translates 尋吾契 as "seeking my fellows", which is not incorrect, but we would take one step further and make it clear that the people in question are not merely the speaker's "fellows" (i.e., friends) but, above all, intimate companions with whom he shares a deep spiritual bond-hence, "kindred spirits". 
In Tao's poem, the character 契 indicates closely-knit human connection where both sides share similar values and ideas. Obviously, this abstract idea has a direct connection with the concrete function of a tally (契) discussed above: as both sides of a tally should fit together seamlessly and only when put together they form a whole, in similar fashion two kindred spirits match with each other (on a metaphorical level) and create a seamless union of mutual understanding. Hence, we can see a clear and evolving continuation of the meanings of 契 in the historical examples we have already mentioned: to carve (Lüshi Chunqiu) $\rightarrow$ to divinate (Shijing) $\rightarrow$ a tally/a deal (Daodejing) $\rightarrow$ to unite/kindred spirits (Peach Blossom Spring).

\section{3. $Q i$ as a Sign of the Times}

契 in Buddhist texts has a variety of uses and meanings, both as a noun, as a verb, and often a qualifier in compound expressions. Earlier uses of this ideogram take the basic meaning "to tally", or "to accord." Its most representative example being the compound 契經, "according sutras", or the "tallying constant". Here, qi has the qualifying meaning of according with the ultimate truth, underlining the idea that sutras are truly words spoken by Shakyamuni Buddha and contain his teachings. They are the true word.

During the Tang dynasty in Buddhist rhetoric, qi begins to acquire the meaning of "understanding", "enlightenment", or "awakening", through a metaphorical shift based on the meaning of "tally". It is related to a vague group, a mixture of old and new metaphors coming together around the turn of the eighth century. The specifics of this question fall beyond the scope of this article, but it is possible to attribute these syncretic developments to the debates regarding gradual and sudden awakening, ${ }^{12}$ and the appearance of esoteric Buddhism in China, with its new metaphors and terminologies, to which new meanings were then affixed.

Qi figures in new verbal compounds such as 契會 “to understand”, 契悟 “accord with awakening", and 契心 “to accord with the mind" that gradually increase in use from the turn of the eighth century and accelerate by the turn of the ninth. ${ }^{13}$

In what are termed Northern Chan texts, belonging to the early Chan period, we can glean the sporadic appearance of $q i$ in a general context of "to understand". The Records of the Teachers and Students of the Laikkā[vatāra] 楞伽師資記 Lengqie shizi ji by Jingjue 浄覺 (683-750), assumed to have been written around the first two decades of the eighth century is one example:

Since coming to this country, I have not even seen people who cultivate the Path, much less anyone who has pacified mind. I often see people who go along creating karma, who have not merged with the path. (Cleary 1986)

至此國來。尚不見修道人。何況安心者。時時見有一作業。未契於道。

(T.85.1284a19-20)

Another can be found in the Northern School lineage text Annals of the Transmission of the Dharma-treasure 傳法寶紀 Chuan fabao ji, from 712:

[Tao]-hsin always guided [Hung-jen] with care, so that [the student] became discerningly enlightened himself. Although he never looked at the Buddhist scriptures, he understood everything he heard. (McRae 1986, p. 263)

信常以意導、洞然自覚。未視諸経論、聞皆心契。(Yanagida 1971, p. 386)

12 For discussions on the sudden vs. gradual debate, and its background in doctrinal classifications, see (Gregory 1987), (Gregory 2002), (Mun 2006). For its effects on Chan hermeneutics see (Buswell 1988).

13 (Sharf 2002, p. 51) notes about the situation of the end of the eighth century: "But it would be misleading to overemphasize the role of any specific exegetical or philosophical tradition in the emergence of the rhetorical style and lexicon common to these works. Rather, these early Ch'an (or "protoCh'an") compositions reflect a shared literary culture and a shared interest in expressing their understanding of Buddhism in a concise and elegant Chinese idiom, circumventing the more technical rubrics of the Buddhist commentarial tradition.". 
Other metaphors being grouped with $q i$ in enlightenment related contexts were e.g., "seal" 印 yin, and "tally" or "amulet" 符 $f u .{ }^{14}$ They are based on similar metaphorical structures. The "seal" is related to older sutra-based metaphors, it is the proof of correct Dharma as used in 三法印 sanfayin "three marks of true Dharma", or alternatively 海印三昧 haiyin sanmei “ocean-seal samadhi"15 where it refers to the mirror-like state of enlightenment of Shakyamuni Buddha, his mind reflecting (duplicating) all phenomena without distortion, as a seal duplicates its engraved pattern in the produced imprint exactly. Two-part magical amulets, tallies, which had imprints in the back, resembling Han dynasty imperial objects had already a pre-Buddhist history in China (Robson 2008, pp. 135-36). The combination of these associations produced connotations of mysterious power, authority and charismatic charm. The close connection of these metaphors is clearly formulated in Huangbo's thoughts on transmitting enlightenment:

Ever since the Tathāgata entrusted the Dharma to Kāśyapa, it has been transmitted through impressing the seal of the mind on the mind. The two minds are not different. If the mind-seal is impressed in emptiness, it does not produce its pattern [impress]. If it is impressed on things, it does not become Dharma. Therefore, it is impressed with the mind on the mind, as the two minds are not different. However, the one sealing and the one sealed are difficult to match. Therefore, those who have attained it are few.

自如來付法迦葉已來。以心印心。心心不異。印著空即印不成文。印著物即 印不成法。故以心印心。心心不異。能印所印俱難契會。故得者少。

\section{(T.48.0382a15-18)}

Of the early Chan period, the so-called Northern Chan texts did not yet display the idea of "silent accord", but in the later part of the period, as the so-called Southern Chan makes its entrance in the teachings of Shenhui, we witness the first formulations of this metaphor. As Huangbo and the Hongzhou School belong clearly to the middle Chan period, we shall first address three texts that are transitional-influential if not quite part of the middle Chan paradigm: records of Shenhui's public lectures; the Baotang School's text Record of the Dharma-Jewel Through the Generations, or Lidai fabao ji 歷代法寶記; and Guifeng Zongmi's 圭峰宗密 (780-841) Chan Prolegomenon 禪源諸 詮集都序.

\section{Shenhui's Definitions}

Heze Shenhui 菏澤神會 (684-758) was a Chan monk, famous for his public lectures held in the 730s when he levelled his accusations on what he termed the Northern School of Chan, the followers of Yuquan Shenxiu 玉泉神秀 (606-706). He argued that they taught an inferior teaching of "gradual practice" against the orthodox teaching of "sudden awakening" of the Southern School, and that the title of the sixth patriarch of Chan belonged rightfully to his teacher Huineng 惠能 (638-713) from whom it had been usurped by the Northern School. These lectures were held between 730 and $732 .{ }^{16}$ Most of his accusations were heavily polemical and his assessment of so-called Northern School unfair. The Heze tradition was not active for long, being overshadowed by the presence of the Hongzhou School by the turn of the ninth century and dying out by the Buddhist persecutions of 845 . However, many of Shenhui's rhetorical strategies and formulations were highly inventive and ended up being absorbed into the general Chan lingo. ${ }^{17}$

From the Dunhuang caves were found text fragments of what professes to be an actual record of the 734 public debate collected under the name Definition of the Truth

\footnotetext{
For Zongmi's use of the tally metaphor see (Broughton 2004, pp. 16-18).

For discussion on oceanic reflection see e.g., (Gregory 2002, pp. 154-57).

開元 Kaiyuan (18), and (20), for further information about the dating see (McRae 1987, p. 234) and additional context see (Welter 2006, pp. 31-33).

(Gregory 2002, p. 22) notes that although Shenhui is seen as a radical polemicist, his actual immediate influence was quite restricted.
} 
of Bodhidharma's Southern School 菩提達摩南宗定是非論 (hereafter Definition). This text was not written by Shenhui himself, but by his lay disciple Dugu Pei 獨孤沛 (dates unkown), possibly around the year $745 .{ }^{18}$ The history of this text is quite complex, as it exists in different, fragmentary versions, and possibly contains many later additions, ${ }^{19}$ but for our purpose, the main episode of interest is not compromised. In the preface to Definition we find the famous story of Huike 慧可 (487-593) cutting off his arm and offering it to Bodhidharma as proof of his sincerity in his quest for the Dharma. Bodhidharma 菩提達摩 (d.u.) affirms Huike's gesture and takes him as his disciple. After this episode the text states in verse:

Bodhidharma, having thus opened up the Buddha knowledge, "intimately according," also transmitted a robe as the proof of Dharma, and conferred them to Huike.

達摩遂開佛知見, 以為密契, 便傳一領袈桬, 以為法信, 授與惠可 (Hu 1988, p. 459)

The Dunhuang Museum manuscript of this text (敦博本), additionally contains the following expressions regarding transmission:

The inner transmission is that of the "accord with the Dharma", with it the certified mind is sealed; the outer transmission is that of the robe, with it the principle meaning is settled.

内傳法契、以印證心。外傳袈桬、以定宗旨. (Db-077r-0045) ${ }^{20}$

These can be considered the first formulations of something akin to "silent accord." Of interest to us here are two elements. First is the use of the term "intimate accord." The second is the role of the robe. Regarding the phrase "intimate accord", at least two things speak in favor of this being peculiar to Shenhui. We know that Shenhui, or Dugu Pei, borrows lineage structures from the Northern School transmission text Annals of the Transmission of the Dharma-treasure or Chuan fabaoji 傳法寶 紀, ${ }^{21}$ even though he publicly disparages them. As was noted above, in this Northern Chan text, the character $q i$ was not directly connected to the idea of transmission, it praised the mental acuity of Hongren, so Shenhui's metaphor contains a new idea. The other reason is that in the exhaustive analysis of the text in (Ibuki 2020), he argues that these terms 密契 and 法契 are at the core of Shenhui's thought and are therefore difficult not to consider his original formulations (Ibuki 2020, pp. 108-7).

The presence and role of the robe is also of interest. Shenhui argues here that the robe functions as proof of the correctness of the Dharma. This insignia-like object can be seen to have two functions. First, it guarantees by definition, unilineal transmission. As the robe is passed down from one generation to the next, Shenhui presents control of the correct source of transmission by way of access to insignia, rather than engaging in debate with a supreme doctrinal formulation of enlightenment. Second, and following this, the presence of the insignia helps to distract the focus away from the substantial side of the debate of enlightenment itself. The sealing of the mind, and the bestowal of the robe are two sides of the same coin. "Intimate" for Shenhui, has also the meaning of secret, not public, accessible only to the initiate.

8 (McRae 1987, p. 234).

19 One manuscript (P.2045) was found by Hu Shi 胡適 (1891-1962) from the Pelliot collection in the 1930's and is included in his 神會和尚遺集, others after the war (P.3488). In the 1980s, one copy in good condition from the Dunhuang Museum (Db.077). A facsimile copy of this can be found in (Yanagida and Shiina 2001). For a detailed summary of the contents and relevance to Shenhui's thought, see (Ogawa 2007, pp. 19-63). (Ibuki 2020) argues that Definitions could be separated into the lecture records and what is referred to as 師資血脈傳 (Shizi xuemai zhuan) The Biographies of Masters and Disciples of Chan Blood Lineage, which could be Shenhui's own initial draft describing the transmission lineage from Bodhidharma that Dugu Pei used as a basis of his own text. For a detailed chart, see (Ibuki 2020, p. 91).

20 Available for perusal in the Ghent University website Database of Medieval Chinese Texts (found under DMCT project, 菩提達摩南宗定是非論 —— 敦煌 遺書 Db.077 (敦博本) 的數位版本). The same section can also be found in the Pelliot collection text (P.2045r0034). https://www.database-of-medievalchinese-texts.be/views/texts/mcgbd_project/showText.php (accessed on 14 April 2021).

21 Written around the year 712 (McRae 1986, p. 33). Translation appended in (ibid., pp. 255-69). 
The theme of "sealing the certified mind" (印證心), finds verification also in other contemporary, or close to contemporary, sources. Similar statements were made in a sermon by Mazu Daoyi 馬祖道一 (709-788), where he states that Bodhidharma "used the Lankavatara-sutra to certify the minds of all sentient beings, lest they not believe in that Dharma of the one-mind." (Jia 2006, pp. 119-20) 唯傳大乘一心之法以楞伽經 印衆生心. 恐不信此一心之法 (T.48.0418b14-15). ${ }^{22}$ The sutra functioned as an insignia of truth, so that he would be believed. Mazu could then explain the use of sutras as a mere "expedient means." As Mazu's teaching of the Buddha-mind was equivalent to the teachings of the sutras, sutras could ultimately be relinquished as having only instrumental value.

Establishing an exact dating or authorship for the Definition is not so important. That these expressions were used by Shenhui, or at least his close circle of followers and were in circulation in Shenhui's name can be attested to by the fact of their presence in the Lidai fabao ji, a lineage record of the Baotang School assumed to have been written between 774 and 781, in which we can observe direct borrowings from Definitions.

\section{The Lidai fabao ji of Baotang}

The Lidai fabao ji professes to record the transmission lineage stories of Chan master Wuzhu 無住 (714-74). The record was an attempt to graft master Wuzhu into the lineage of the Silla Master Wuxiang (Musang) 無相 (694-762). It received hard rebuke from Wuxiang's actual Dharma heirs. ${ }^{23}$ While the text itself was not without influence, as a school the Baotang was short-lived.

Dating the text to the turn of the 780s, means that there was ample time for Shenhui's lecture records to circulate south to the Sichuan area where the Baotang movement was active. The close to direct borrowings from Shenhui's Definition are evident. $^{24}$ In a section recounting the episode of Huike cutting off his arm in front of Bodhidharma, both the content of the story and the order of exposition are the same. The text remarks: "The Great Master then silently transmitted the mind-pledge, and passed on to him a kāṣāya robe." (Adamek 2007, p. 314) 大師默傳心契. 付袈装一領 (T.51.0181a22-23).

Silent transmission of the mind-pledge is also mentioned when the record pits Bodhidharma against Gunabhadra. The text explains of the latter:

All of the above were translator-Trepitakas and not Chan masters. All of them transmitted the teachings of the written word. Patriarchal Master Dharma was in the lineage of the Chan Dharma. He did not bring a single word, [just] silently transmitted the mind-seal. (Adamek 2007, p. 310)

以上盡是譯經三藏。不是禪師。達摩祖師宗徒禪法不將一字教來。默傳心印。

(T.51.0180b29-c02)

The reason for the contrasted positions of Gunabhadra and Bodhidharma was to discredit the Northern Chan text Records of the Teachers and Students of the Lañkā[vatāra], which held the Chan lineage to start with Gunabhadra as the first patriarch, who then transmitted the Lañkāvatāra sütra to Bodhidharma (Cleary 1986, p. 32). Here, "silence" takes a stance against sutras and the false lineage of the North. The text also employs Shenhui's term "intimate accord":

He [Wuzhu] chanced to meet the white-robed layman Chen Chuzhang, whose origins are unknown. People then called him an incarnation of Vimalakīti. From the moment that he met the Venerable [Wuzhu] he privately sealed their mutual understanding, and silently transmitted the mind-Dharma. Hav-

22 This sermon is recorded in Zongjing $l u$ 宗鏡錄, a later work, but (Jia 2006, pp. 119-20) argues the sermon to be authentic.

23 E.g., Beishan lu 北山録 (806), see (Adamek 2007, p. 3).

24 For Shenhui's influence on Lidai fabao ji see (Yanagida 1983, pp. 25-29). 
ing obtained the Dharma, the Venerable completely cut through thinking and ceased all restless anxiety, abandoning phenomena and characteristics. (Adamek 2007, p. 346)

忽遇白衣居士陳楚璋。不知何處人也。時人號爲維摩詰化身。説頓教法。和 上當遇之日。密契相知。默傳心法。和上得法已。一向絶思斷慮。事相並除。

\section{(T.51.0186a21-24)}

This episode happens in the very beginning of the narrative and is the first encounter that leads Wuzhu on his quest for enlightenment, it is a far cry from a transmission event making the Dharma-heir of Wuxiang. Considering the marginal role this meeting has in Wuzhu's long and winding story arc, the use of the phrase in this episode seems very off-hand and formulaic and seems to hold no special meaning.

The silent "sealing" and "according" in Lidai fabao ji seems to have two distinct uses. The second episode refers in a very general manner to the idea that the Chan school's teaching has, throughout history, been transmitted secretly from person to person, rather than by way of sutras. The first and the third episodes follow Shenhui's Definition, where the according resembles the master deeming a person worthy of becoming a vessel of Dharma. The narrative point of view is that of the master's position, not that of the student's.

\section{Zongmi's Prolegomenon}

Guifeng Zongmi was a monk and member of the literati, considered the fifth patriarch of Shenhui's Heze tradition, as well as belonging to the Huayen tradition following Chengguan 澄觀 (738-839). ${ }^{25} \mathrm{He}$ is a significant figure for Chan historiography, because from his writings, the famous Chan Prolegomenon 禪源諸詮集都序 (T.2015), Inquiry into the Origin of Humanity 原人論 (T.1886), and his commentary of the Scripture of Perfect Enlightenment 圓覺經大疏 (X.234) give us reasonably accurate and dateable information of the Chan traditions of his time. He was also a contemporary of Huangbo, and while Zongmi's Prolegomenon is at times critical of the Hongzhou School's teaching, it serves as a valuable repository of knowledge, since at the time of its writing, it would possibly have been the teachings of Huangbo that he had in mind. These two figures are also connected by their friendship with Pei Xiu.

Zongmi indeed mentions "silent accord" in his Prolegomenon, but it is immediately clear that his approach is quite different from Shenhui's Definition. In Zongmi's Prolegomenon he explains how the principle Chan teaching has been misunderstood, and that it is for the sake of these people that he sets the record straight. Once again, it is the encounter of Bodhidharma and Huike that sets the scene for explaining "silent transmission", although Zongmi's version is completely different from the "arm cutting" scenario depicted in Definition. Zongmi sets the meeting of Bodhidharma and Huike in a context of explaining the concept of "natural knowledge," or wisdom, 知 zhi, which remains even after "all relations are cut off" (諸縁絶). This is to argue against the understanding that the mind is destroyed (迦滅) in the process of enlightenment, a criticism directed toward the Northern School. When Huike gives proof that his mind is not destroyed, but there remains what is "known only by oneself, for which there are no words" (了了自知言不可及) Bodhidharma recognizes Huike's enlightenment as correct.

So, as long as Huike's answers did not exactly match, he [Bodhidharma] would merely reject all mistaken ideas, urging him to practice, and dared not use the word "knowledge." Only once the person himself manages to awaken, can the teacher say "It is so." After the person himself has cleared and verified the essence, can the Master give his certifying and help to cut off all remaining doubts. This is why it is said "The Mind-seal is transmitted

25 For Zongmi's biography and complications in affiliation with Heze Shenhui, see (Gregory 2002, pp. 27-88) and (Broughton 2004, pp. 12-16). 
in silence." Here "silence" means only, "not using the word 'knowledge'," not relinquishing the use of words entirely. This is the way of transmission up to the six patriarchs.

若所答不契。即但遮諸非更令觀察。畢竟不與他先言知字。直待自悟方驗實。 是親證其體。然後印之令絶餘疑。故云。默傳心印。所言默者。唯默知字。非 總不言。六代相傳皆如此也。(T.48.0405b08-15)

Zongmi's definition of what "silence" means is a rethinking of Shenhui's original idea. Zongmi frames his argument of natural knowledge by claiming that transmitting the mind in India using sutras and treatises was common. It was only in China that people "lost sight of the mind", "getting caught up in words and letters," and mistaking them for the real thing. This is the reason for Bodhidharma's relinquishing of letters and preaching the "mind" by saying that "mind" is a name only, its true body being without words. For Zongmi, the sutras contain the same truth as the wordless teaching and calling it "silent" is not to deny the use of language. It was only by relinquishing the term "knowledge", that Bodhidharma managed to teach it correctly. Zongmi continues:

In the time of Heze Shenhui, other schools were competing for their propagation and success. Even if they were chasing after the "silent accord," they were not able to achieve it. Shenhui recalled what had been prophesied by Bodhidharma, that "the teaching will hang by a string after six generations," and fearing for the principle meaning of the school to be destroyed, did his utmost to prevent this and preached clearly "The Excellent gate of Knowledge," leaving it to the shallowness or depth of practitioners' attainment.

至荷澤時他宗競播。欲求默契不遇機縁。又思惟達摩懸絲之記達摩云。我法 第六代後。命如懸絲恐宗旨滅絶。遂明言知之一字衆妙之門。任學者悟之淺 深。(T.48.0405b12-5)

This argument is constructed to vindicate Shenhui's teachings by completely reconfiguring them. Zongmi makes the point that it is the misconception of language, rather than the nature of language that is the problem. He argues that both Bodhidharma and Shenhui in their respective treatments of preaching "knowledge," acted out of necessity, by expediently responding to their circumstances. What Bodhidharma concealed, Shenhui brought to light for the sake of people. This shows how for Zongmi, the "silence" helps to build his own argument that is constructed around his own master metaphor of the "tally" 符, where sutras and the wordless teaching, gradual and sudden teachings, etc., are all matching halves of the great "tally" (Broughton 2004, pp. 16-17). Zongmi's project was to unite the scholarly side of Buddhist textual study with Chan praxis. His "accord" is a more complex philosophical concept that aims at the unity and tallying of the entire Buddhist cosmos, with all opposites included and explained, not a metaphor for transmission.

\section{In Southern Chan the $Q i$ Is Silent}

The centrality of the concept of "silent accord" for Huangbo can be analyzed from a number of viewpoints. We should separate the question of its centrality to Huangbo from its role for the development of the Hongzhou School, and Chan in a larger context, as the proof for the first does not yet indicate proof of the latter.

There is little doubt about the role "silent accord" held for Huangbo. There is its appearance in the main text of Essentials and a gatha by Pei Xiu reflects the same message. As was noted above in the excerpt on matching minds, it can be seen as a very concrete, intimate activity that happens between the master and the student. It is as if the "sealing" is the more mechanical description of what happens, and "matching" the tally is the art of it. This sets Huangbo's formulation of the metaphor apart from the early Chan texts. Its centrality is also bolstered by Pei Xiu's "Transmission of the 
Mind Gatha" 傳心偈, ${ }^{26}$ a fourteen-couplet poem summarizing his understanding, appended to the end of the main text of Essentials' redaction in the Jingde chuandeng lu 景徳傳燈録. ing: ${ }^{27}$

Pei's gatha's beginning couplet pronounces head-on the core of Huangbo's teach-

Mind cannot be transmitted， 心不可傳

it can only be transmitted via [qi]. 以契為傳

(T.51.0273a12)

The first line bluntly negating the possibility of transmitting mind, refers to the paradox of transmission as non-transmission. That in the event called "transmission," nothing actual, no-thing, is transmitted. However, the second line of the gatha confirms that mind can indeed be transmitted—only by the means of 契 $q i$, "accord." The couplet's two themes intertwine in the main body of text. In a section where Huangbo explains the meaning of no-mind 無心 he adds how this Dharma is attained:

These dharmas are the mind; there are no dharmas outside of the mind. This mind is the dharmas; outside of the dharmas there is no mind. The mind is of itself no-mind, yet it is without no-mind. If you take the mind as no-mind, you make the mind into something that exists. Just conform with it in silence, ceasing the various [types of] conceptualization. Therefore it is said, "the way of words is cut off, and the activities of the mind cease." (McRae 2005, p. 16)

此法即心。心外無法。此心即法。法外無心。心自無心。亦無無心者。將心無 心。心却成有。默契而已。絶諸思議。故曰言語道斷心行處滅。

(T.48.0380b11-14)

On the same topic Huangbo continues:

You cannot seek the mind with the mind, you cannot seek the Buddha with the Buddha, and you cannot seek the Dharma with the Dharma. Therefore, trainees should achieve no-mind right now. Simply conform with [the mind] in silence-if you try to use the mind you will miss it. To transmit the mind with the mind-this is the correct view. I warn you, do not look outward and chase after realms but recognize that the realms are the mind. [To commit this error would be] to accept the thief as one's own child. (McRae 2005, p. 22)

不可以心更求于心。不可以佛更求於佛。不可以法更求於法。故學道人直下 無心默契而已。擬心即差。以心傳心此爲正見。買勿向外逐境。認境爲心。是 認賊爲子。(T.48.0381b01-5)

Further:

Therefore, the Buddha has said, "I have truly not attained anything in bodhi." There is only silent conforming [with the mind]. (McRae 2005, p. 24)

故佛言。我於菩提實無所得默契而已。(T.48.0381c04-5)

These references give us a good understanding of Huangbo's idea of the noncontent of enlightenment, or the transmission as a non-transmission. It is consistent with the early Hongzhou school teachings of merely awakening to what already is without allowing the discriminating mind to arise. These three occurrences are considered to be original to Huangbo and are present in all redactions of the text.

$26 J i$ 偈 means "Buddhist verse", i.e., a gatha. In Chan there developed a practice of mind-gathas that summarize one's understanding. For more detailed discussion on gatha's in general, see (Mazanec 2017, pp. 98-99). This gatha is not included in all manuscripts of Essentials, and some manuscripts, such as the Kan'ei 寛永本 and Keian 慶安本 manuscripts, place it in the fifth chapter (Ui 1992, n. 88).

27 For relations of Huangbo's teaching to other Hongzhou figures, such as Mazu, see (Poceski 2007, pp. 157-92) and (Wright 2004, pp. 125-29). 
The formulation of "silent accord" in the sense Huangbo uses it, can be dated to his times. The Hongzhou School's first lineage document, the Record of the Baolin Monastery 寶林傳 Baolin zhuan (801), does not yet contain the term "silent accord". We find a single use of the phrase 得契心 "obtaining accord with mind," and a single use of the phrase "silently understanding" 默然契會, appearing in a story where Nagarjuna manifests himself as a full moon. Otherwise, in the sections that are extant, which unfortunately do not include the sections of Mazu and his disciples, $q i$ is scarcely present.

However, Ehu Dayi's 找湖大義 (746-818) epitaph written by Wei Chuhou 韋處厚 (773-829) in 818 contains a record of dialogue between Dayi and Emperor Shunzong (r. 805) during the Zhenyuan reign-period (785-804) when he was the Crown Prince. The prince asked Dayi: "What is Buddha-nature?' Dayi answered, 'It does not leave that which Your Highness is asking.' Then the prince silently understood [默契] the mysterious teaching." (Jia 2006, p. 49.)

Jia introduces this dialogue as proof of an early example of an encounter dialogue. The relationship with encounter dialogues will be addressed below. For now, this gives dateable proof of the term being available for Huangbo and shows that the context in which it appears is not tied to the early Chan period texts, pointing already towards a form that resembles the mature encounter dialogues. What it shares with Huangbo's formulation, is the inclusiveness of viewpoint of the student. Rather than have the master accept the student, the dialogue depicts a special moment when the student "matches" the meaning of the master's retort.

\section{Facts and Fictions of Transmitting Mind}

It is the fourth occurrence of "silent accord" in Essentials, which can be seen as problematic. Here "silent accord" is clearly tied to the narrative event of enlightenment, the event of transmission through the depiction of a mythical encounter. This lengthy episode is first quoted in full, and then analyzed part by part.

Question: The Sixth Patriarch did not understand written scriptures, so why did he receive the transmission of the [Fifth Patriarch's] robe to become a patriarch? The elder [Shen]xiu was the chief monk among the five hundred [disciples]. He [served as] instructor for them, lecturing on thirty-two sutras and treatises. Why did he not [receive the] transmission of the robe?

The master said: Because he (i.e., Shenxiu) took the mind as extant and considered that there were conditioned Dharmas to be cultivated and realized. For this reason the Fifth Patriarch transmitted [the Dharma] to the Sixth Patriarch. At the time the Sixth Patriarch simply conformed in silence and received the intimate conferral of the profound meaning of the Tathägatas. Therefore the Dharma was conferred on him. Haven't you heard it said that

The Dharma is fundamentally the Dharma as non-Dharma;

the non-Dharma is the Dharma and still the Dharma.

In the present conferral of the non-Dharma,

how can the Dharma ever have been the Dharma? ${ }^{28}$

Only if you understand this idea can you be said to have "left home," and only then is it well that you undertake spiritual training.

If you do not believe me, then why did head monk [Hui]ming chase after the Sixth Patriarch [all the way] to Mount Dayu? The Sixth Patriarch asked him, "What did you come for? Do you seek the robe or the Dharma?" Head monk [Hui]ming said, "I have not come for the robe but only for the Dharma." The Sixth Patriarch said, "You should concentrate your thoughts for just

28 This is a mind-gatha by Mahakasyapa that appears in the Baolin zhuan. 
a short while, without thinking of good and evil." [Hui]ming did as he was told. The Sixth Patriarch said, "Do not think of good and do not think of evil. When you've got it just right, show me the face you had before your parents were born." At these words, [Hui]ming suddenly [experienced a] silent conformance [with the Dharma]. He then paid obeisance [to the Sixth Patriarch] and said, "When a person drinks he automatically knows [whether the water is] hot or cold. When I was in the assembly of the Fifth Patriarch, I labored pointlessly for thirty years, and only today have I been able to eliminate my previous errors."

The Sixth Patriarch said, "So it is. Only after coming here have you understood the ineffability of [the saying] 'the patriarch [Bodhidharma's] coming from the west, directly pointing at people's minds, and seeing [Buddha]nature and achieving Buddhahood.' " (McRae 2005, pp. 40-41)

問六祖不會經書。何得傳衣爲祖。秀上座是五百人首座。爲教授師。講得三十 二本經論。云何不傳衣。師云。爲他有心是有爲法。所修所證將爲是也。所以 五祖付六祖。六祖當時秖是默契。得密授如來甚深意。所以付法與他汝不見 道。法本法無法。無法法亦法。今付無法時。法法何曾法。若會此意。方名出 家兒。方好修行。若不信云何明上座走來大庆嶺頭尋六祖。六祖便問。汝來求 何事。爲求衣爲求法。明上座云。不爲衣來。但爲法來。六祖云。汝且暫時斂 念。善惡都莫思量。明乃禀語。六祖云。不思善不思惡。正當與麼時。還我明 上座父母未生時面目來。明於言下忽然默契。便禮拜云。如人飲水冷煖自知。

(T.48.0383c19-384a03)

This is a dense and suggestive episode. It implicitly expresses and connects the ideas reminiscent of the four slogans, and explicitly ties them around the idea of "silent accord." It also presents an encounter dialogue style discussion between Huineng and Huiming.

We can make several observations. First, the episode seems too long and full of literary references to be a verbatim record of an oral exposition. It evokes the story of the Platform Sutra of the Sixth Patriarch 六祖壇經 Liuzu tanjing, in that "silent accord" is something that happens between Hongren and Huineng, a further distinction to early Chan period texts that treated the meeting of Bodhidharma and Huike as the prime example. The Platform Sutra was not the first text to argue for the preference of Huineng as the sixth patriarch, and while the term "silent accord" does not appear in the Platform Sutra, the latter part of this episode references it directly in the form of the dialogue of Huineng and Huiming.

What gives us pause, is that the version quoted in Essentials is not consistent with its earliest extant version, found in Dunhuang (Yampolsky 1967). There is still no consensus on when the Platform Sutra was in fact written, but probably the Dunhuang text is based on a text formulated around 780 or shortly afterwards. ${ }^{29}$ The part of the story of the meeting of Huineng and Huiming differs from the Dunhuang version, where the dialogue is shorter and Huiming is still called Huishun (Schlütter 2007, p. 390). The Dunhuang manuscript also does not contain the phrase "Do not think of good and do not think of evil. When you've got it just right, show me the face you had before your parents were born."

Besides referencing the Platform Sutra, the episode also seems to encapsulate many aspects relevant to the Hongzhou School. Employing the legend of Huineng as being illiterate, and not understanding the words of scriptures, suggests the idea that "silent accord" is not dependent on them. It is thus implicitly outside the scriptures, ${ }^{30}$ and it does not rely on words and phrases. Huineng just remains silent and

29 McRae argues for 780s (McRae 2003, p. 58), Schlütter notes ninth century in (Schlütter 2007, p. 385).

30 Being outside the scriptures does not necessarily imply the tradition being separate. It is possible to understand this as being equivalent to Mazu's teaching that sutras contain the same meaning as "sudden awakening", but studying the sutras confuses the mind. 
does not pronounce any verbal formulations of his understanding in the moment of transmission.

Huineng's words to Huiming: "Only after coming here have you understood the ineffability of [the saying] 'the patriarch [Bodhidharma's] coming from the west, directly pointing at people's minds, and seeing [Buddha]-nature and achieving Buddhahood" " contain two of the four Chan slogans, as well as establish a connection between "directly pointing" and the Hongzhou school's fundamental teaching, "the patriarch coming from the West." The meaning of the patriarch coming from the West is equivalent to the idea of non-transmission. The reason for Bodhidharma coming from the West was to show that Buddha-nature was already in China, as it is within everyone. This formulation was not only doctrinal, it also had political implications. The true teaching of the Buddha had always been in China, it was just the outer forms of sutras and rituals that could help one to awaken to this fact that was already the case, and universally available to all. This was an important idea that aided the spread of the Hongzhou School.

The Chan slogans are weaved into the narrative and become tied with the Hongzhou's core teachings and style of transmission. The idea of universal enlightenment points towards a stated difference between the vertical unilineal transmission lineage argued for by Shenhui and the tree model of lineage that opens up horizontally and leads eventually to ideas such as "two lineages and five houses," subsequently perpetuated in later Chan records. ${ }^{31}$ Again, the focus is not on the bestowal, the "according" is performed by the student.

\section{Dealing with Uneasy Silences}

The textual proofs seem to allow us to make the claim that Huangbo, if not as a historical person, as a literary figure, preached the idea of "silent accord," a new formulation of an older idea, propagated a form of transmission where the student silently accords with the words of the teacher, tallying his mind and gaining awakening. The changes to the older, unilineal transmission model where the master recognizes a future heir and seals his level of understanding is clear. These changes can be seen as precursory formulations of what later develops into encounter dialogue.

Nevertheless, the extent of influence is tied to the question of reliability of the record of Essentials? Can we trust its testimony? There are four points of criticism that can be levelled against Pei Xiu's records. First is the known additions of the second record by Pei Xiu, Wanling Record. Second, the argument by (Wright 1998) against assuming that Pei Xiu was necessarily always faithful in his renderings of Huangbo's sermons. Third, the (Welter 2000) claim that the text was not completed until 1036. Fourth, one that the text itself seems to raise in the form of a quotation from a late version of the Platform Sutra.

The first point of criticism is that we know that there are serious problems with the authenticity of the Wanling Record, as it contains dialogues that could already be considered encounter dialogues. This is evidence of later addition. ${ }^{32}$ While this evidence does not apply directly to Essentials, it should make us wary of any clues to the same effect. One such clue is the dialogue of Huineng and Huiming, a borrowing of a non-early version of the Platform Sutra.

Wright warns us against reading the recorded sermons in the Essentials naively as faithful renderings of Huangbo's oral delivery and notes the presence of Pei's literatibrush. Pei was trained in Buddhist philosophy and would have understood and organized Huangbo's teachings according to his own preformed designs and ideas (Wright 1998, pp. 6-7). It is most likely true that in some aspects the final text differs from the oral delivery it was based on. It was finished years after the initial records

The "two lines and five houses" has also been proven a retroactive formulation. For deconstruction of this idea, see (Jia 2006, pp. 107-8).

e.g., Yanagida in (Iriya 1968, pp. 172-76). (Jia 2006, pp. 133-34) notes Yanagida's argument and concurs "it must have been reshaped in later times." 
were written down. However, the drafts were inspected by Huangbo's disciples, who most probably added material to the record based on their own lecture notes. And there is no proof to suggest that Pei Xiu would have had a hand in constructing some argument or claim related to "silent accord" that would not have its source in Huangbo's original teachings. If it could be argued that Pei Xiu's affinity with Zongmi, for example, made him prone to skew his understanding closer to the Heze tradition as propagated by Zongmi in his Prolegomenon, perhaps there would be a case to be made. However, as it stands, Zongmi's and Huangbo's explanations of "silent accord" have very little to do with each other, so, at least regarding this metaphor, any additions by Pei Xiu do not seem plausible.

(Welter 2000, p. 102, n. 21) claims: "The compilation of the full text of Huang-po's teachings did not appear until 1036, when it was recorded in the T'ien-sheng kuangteng $l u$ [Tiansheng guangdeng $l u$ ]." This is not a sustained argument by Welter, only a mention in a footnote, but it seems that Welter bases his claim on the commentary by Yanagida published in Iriya's translation (Iriya 1968, pp. 172-82). In his commentary Yanagida explains the redactions appearing first in 1036 in Tiansheng guangdeng lu, and later attached to Jingde chuandeng $l u$ (Hereafter JDCDL) in 1048. ${ }^{33}$ While it is true that parts of Essentials and Wanling Record have been altered, Yanagida does not explicitly say anything regarding the section of the slogans, and Iriya comments in his translation-that, as a set phrase-the slogans appear probably for the first time in Essentials (ibid. p. 89). Welter notes himself that most of the slogans were known separately already during the Tang, just not as a complete set (Welter 2000, p. 81).

It is not necessary to assume that, because the text was published in 1036, the material it contains is not significantly older. After all, much of the middle Chan period material circulated as private records, and it is mainly during the Song period that they were collected and published as public records. It is possible to assume that the compilers of the JDCDL, who favored the Fayan lineage, were not as interested in including everything, or simply were working with a copy of the text that was not complete. However, this remains speculation.

Lastly, the vexatious phrase "show me the face you had before your parents were born" is most certainly not dateable to the time of Huangbo. What makes this phrase problematic, is that the version of the Platform Sutra cannot be dated exactly. It is most likely that it refers to the Chao edition, which is known via the Japanese Kōshōji edition. It has a preface by Chao Zijian, dated 1153, and based on a manuscript by Wen Yuan (Chao Jiong) prefaced in 1031. To what extent its reproduction in the Kōshōji edition is faithful, we do not know, but Schlütter deems it fairly accurate (Schlütter 2007, pp. 399-400).

The preceding Huixin edition from 967, does not contain the phrase. While this means that dating the section remains inconclusive, it is either possible that prior to the publication of Tiansheng guangdeng $l u$, the fourth section was created based on the Chao version of the Platform Sutra, or that a previous rendering of the section was furbished with the latest details using the Chao manuscript. However, this, again, remains speculation.

\section{Tallying Up-Huangbo and the Hongzhou Heritage}

Even if we cannot date the fourth episode, we still have to consider the question of influence. We argue that despite the dubious dating of the fourth episode, the use of "silent accord" contributed greatly to the general development of the metaphor of $q i$, and the context it appears in can be seen as a precursor of the mature encounter dialogue model, in the sense of a special event, the moment of enlightenment as the moment of transmission. 
We defined the genealogical model of Chan as a perpetual familial system that is based on organizing lineages through which enlightenment is transmitted down generationally, from master to student. The engine that perpetuates this model is the handing down of the model, generational encounters, recorded in lineage records. What is recorded, are important, exemplary dialogues that tell of the moments of transmission-dialogues describing the awakening of the student, encountering the master.

Jia (2006) notes that the Hongzhou School employed encounter dialogues from very early on, although they lack some features that are present in their mature form. Zongmi gives examples of Chan dialogues in his Prolegomenon that portray how Chan masters "awaken their students suddenly by mysterious resonance without leaving any trace of language" (Jia 2006, p. 49). His examples contain dialogues by Mazu and Shitou and he describes them thus: "In a word, they just followed the conditions and responded to the encounters at the given moments" (ibid.). The "encounter" 機 $j i$ is the same in encounter dialogue, jiyuan wenda 機縁問答.

The text of Essentials is situated between two lineage records, which strongly present the Hongzhou School. As mentioned above, the Record of the Baolin Monastery 寶林傳 Baolin zhuan was published in 801, and is a record that was produced by the Hongzhou School. The second lineage record is the Collection of the Patriarchal Hall 祖 堂集 Zutangji (952) (hereafter Patriarchal Hall). The Patriarchal Hall was written as a public document, ${ }^{34}$ and it was also the first to include various lineages in the same collection, affirming the norm of horizontally spreading lines of transmission. ${ }^{35}$

McRae notes that the so-called "encounter paradigm" of recording meetings of master and student to implicate lineage is already in existence in Baolin zhuan, but recording of the dialogue where enlightenment happens, appears only later in the Patriarchal Hall (McRae 2003, pp. 96-97, 112-15). While the encounter dialogue format was arguably already formulating around the time of the Baolin zhuan, or shortly after, it is not present in the text. The shift from recording "that it happened" in Baolin zhuan, to "exactly what happened" in Patriarchal Hall, is momentous. While Baolin zhuan did not yet employ fully the metaphor of "according", the Patriarchal Hall, on the other hand, contains dozens of $q i$, in various phrasings. Often in the form of "intimate accord" (密契) and describing encounter dialogue style repartees. In fascicle 14, we find the story of Mazu's Dharma-heir Baizhang Huaihai 百丈懷海 (720-814).

Later he [Baizhang] became a monk, and setting his ambitions on the supreme vehicle, went directly to hear Mazu's Dharma talks. Mazu took one look at him and had him enter his quarters. The master [Baizhang] intimately accorded with the "gate of entry" and never resided anywhere else.

自後為僧。志慕上乘, 直造大寂法會。大寂一見, 延之入室。師密契玄關, 更 無他往。

We can easily see that while the element of Mazu immediately recognizing Baizhang's potential, and inviting him for private instruction is present, "intimate according" clearly refers to Baizhang. Baizhang finds, or strikes, accord with the "gate of entry," which means both physically a gate in a Chan temple, and metaphorically the entry into the mysteries of Buddhism. Moreover, it is noted that Baizhang does not just have an awakening experience, he strikes accord with Mazu, and "never resides anywhere else."

34 For details see (Welter 2006, p. 65).

35 Kinugawa Kenji's hypothesis separates three different stages based on the two prefaces of the text: an original work in one fascicle in 952; an enlarged early Song dynasty edition in ten fascicles; the division of the previous into a new twenty fascicles in the Korean reissue of 1245 (Welter 2006, p. 64). Based on linguistic analysis, Kinugawa argues that the extant text contains phrasings that are peculiar to Song dynasty language (Kinugawa 2012, pp. 31-58). However, while some of the linguistic phrasings used in the 1254 manuscript may well represent a newer style, we argue that the contents, especially regarding the metaphor in question, retain their original formulation from the 10th century. 
The other significant factor is the focus on the encounter situation 機縁, the idea of "according" as responding to circumstances, the matching of minds. In fascicle 4 of the Patriarchal Hall, a dialogue is recorded between Mazu and Zhaoti. Zhaoti, a disciple of Shitou, has come to Mazu to request "Buddha knowledge and insight" (佛知見), but he fails to grasp Mazu's retort, "There is no knowledge and insight in Buddha."

You have obviously not yet understood the "essentials of mind" taught in Caoxi. You should go back to Shitou. The Master [Zhaoti], on Mazu's instruction, returned to Shitou. After arriving he finally, as Mazu had said, "accorded with his (karmic) situation" and gained awakening.

似未見石頭曹溪心要耳。汝應却歸石頭。師遂依言而返, 造石頭, 果應大寂 之言, 契縁悟達。

The main post-Huangbo, but arguably pre-Song text seems to contain uses of $q i$ that take their lead from the "silent accord" of the Essentials, with or without the qualifier. It is the presence of such metaphorical combinations, the joining of "according" with encounters that lead us to argue that despite the Kinugawa hypothesis, these terms were paired earlier rather than later. It could be argued that the metaphor of Essentials has helped to bring a new layer of meaning to the metaphor, "striking accord."

\section{Encountering the Right Teacher and Striking Accord}

As we recall, the Hongzhou style of horizontal branching of Dharma meant that the Dharma could spread far and wide. Already many of Mazu's immediate disciples branched out their own temples, and during the ninth century, this practice would only increase, the short period of Huichang Buddhist persecutions (841-845) notwithstanding. ${ }^{36}$ It was the norm that monks would travel all over China, from mountain to mountain, looking for the right teacher. That is, the teacher with whom one could strike accord with. The commentary to case 31 of the The Blue Cliff Record 碧巖録 Biyanlu, a Song period collection, describes it as follows:

When the ancients travelled on foot to visit the monasteries everywhere, they only had this matter on their minds: they wanted to discern whether the old teacher on the carved wood seat possessed eyes or did not possess eyes. The people of old would stay if there was mutual agreement in a single word, and would leave if they did not agree in one word. (Cleary and Cleary 2005, p. 195)

古人行脚。遍歴叢林。直以此事爲念。要辨他曲録木床上老和尚。具眼不具 眼。古人一言相契即住。一言不契即去。(T.48.0170b06-08)

This description is already nostalgically harkening back to the good old days when everything was settled in one word. A record of such ancient behavior can be found in the same Blue Cliff Record, in the commentary section of case 20:

Haven't you heard? Wu Hsieh [Wuxie] went to see Shih T'ou [Shitou]. He had made an agreement with himself beforehand saying, "If there's accord at the first word I'll stay; otherwise, I'll go." Shih T'ou [Shitou] just sat on his seat; Hsieh [Xie] shook out his sleeves and went out. Shih T'ou [Shitou] knew that Wu Hsieh [Wuxie] was a vessel of the truth, so he had extended his teaching to him. But Hsieh [Xie] hadn't understood his meaning; he had announced his departure and gone out. When he got to the gate Shi T'ou [Shitou] called out to him, "Reverend!" When Hsieh [Xie] looked back, Shih T'ou [Shitou] said, "From birth to death it's only this; don't seek anymore

36 For Mazu's disciples and their temples, see (Jia 2006, pp. 31-45), also (Poceski 2007, pp. 85-124). 
for anything else by turning your head and revolving your brain." At these words Hsieh [Xie] was greatly enlightened. (Cleary and Cleary 2005, p. 132)

不見五洩參石頭。先自約曰。若一言相契。即住。不然即去。石頭據座。洩 拂袖而出。石頭知是法器。即垂開示。洩不領其旨。告辭而出至門。石頭呼 之云。闍黎。洩回顧。石頭云。從生至死。只是這箇。回頭轉腦。更莫別: 求。 洩於言下大悟。(T.48.0160c12-17)

We can assume this story to be a later fabrication, as in Shitou's (700-790) day, the rhetorical expressions used in this case were probably not yet developed, but it describes the development of the metaphor of $q i$. What this and the previous examples show us, is the close connection between the Hongzhou model of "silent accord" as a kind of encounter dialogue, and the way this "silent accord" has become a part of the general metaphor of $q i$, striking accord.

Beyond this, we also see further developments of the metaphor, where the "tallying" can refer to accordance of words with actions. In the main case of Blue Cliff Record 22, in response to Xuefeng mentioning "a turtle-nosed snake on South Mountain", "Yun Men [Yunmen] took his staff and threw it down in front of Hsueh Feng [Xuefeng], making a gesture of fright." (Cleary and Cleary 2005, p. 144) 雲門以拄杖。㼠向 雪峰面前 (T.48.0162c09). Yuanwu writes in his commentary that "Just because he likes the way Yun Men [Yunmen] accorded perfectly with Hsueh Feng's [Xuefeng] meaning, therefore Hsueh Tou [Xuedou] makes his verse on it." (Cleary and Cleary 2005, p. 149) 雪䆩只爲愛雲門契證得雪峰意。所以頌出 (T.48.0163c01-2). This is a case of matching intentions, despite the difference in the vehicle of communication. It is a back-and-forth of equal peers, kindred spirits.

\section{Conclusions}

As we have seen, the nature of enlightenment and its transmission was in the process of constant negotiation throughout the centuries in Chinese Chan Buddhist discourse. One of the major metaphors in this discussion was the concept and metaphor of "according" mind with enlightened mind. The role of language and verbal formulations of the truth of enlightenment was always problematic, and the concept of "silence" was used by many Chan masters to describe the ineffability of ultimate truth. Especially for the Hongzhou School, and Huangbo, the true essence of Buddhadharma was transmitted from master to student in the act of "silent according." Language was considered instrumental-it merely created the circumstances for the student to match his mind with the ineffable meaning behind the master's words.

Huangbo's formulation of "silent accord" was not without predecessors and also some of his contemporaries used similar type of language, but in Huangbo's "silent accord" rhetoric we can witness a specific and pivotal usage of the term as a core metaphor for mediating enlightenment and transmission, more focused on the event of enlightenment. Furthermore, Huangbo's teachings had arguably a significant impact on the further development of what was later termed encounter dialogue. It is not our intent to overstate the role of Huangbo as a singular figure towering over others, certainly many other private records were also in circulation during the middle period. However, we wish to draw focus on the fact that of the texts available to us from the middle Chan period, when the Hongzhou School was at its peak, Huangbo's teaching in the Essentials is the most probable source for the further proliferation of the "according" as witnessed in the Zutangji. It was the Hongzhou School that changed the unilineal transmission system, and produced the lineage collection Baolin zhuan, which was the basis for building the lineage model of Zutangji.

While some of the sermons in Essentials cannot be definitively dated as original, it seems safe to assume that the further literary polishings were the handiwork of his successors. Moreover, one could argue that even a fairly late creation date for the fourth occurrence of "silent accord" would still be telling of the central position that the concept had in Huangbo's thought. The episode that linked all the important 
Hongzhou concepts with the new collection of slogans and encounter dialogue, was built around his core teaching-"silent accord."

Author Contributions: Conceptualization, A.J. and T.T.; methodology, A.J. and T.T.; formal analysis, A.J. and T.T.; investigation, A.J. and T.T.; resources, A.J. and T.T.; writing-original draft preparation, A.J. and T.T.; writing-review and editing, A.J.; All authors have read and agreed to the published version of the manuscript.

Funding: This research received no external funding.

Institutional Review Board Statement: Not applicable.

Informed Consent Statement: Not applicable.

Data Availability Statement: Not applicable.

Conflicts of Interest: The authors declare no conflict of interest.

\section{References}

\section{Primary Sources}

Ctext $=$ Chinese Text Project. Internet database. Editor Donald Sturgeon. https://ctext.org/ (accessed on 14 April 2021).

Ghent University Database of Medieval Chinese Texts. Editor in Chief / Project Director, Christoph Anderl. https://www.databaseof-medieval-chinese-texts.be/ (accessed on 14 April 2021).

SWJZ = 說文解字. Beijing: Jiuzhou chuban she, 2001.

$\mathrm{T}=$ Taishō shinshu uaizōkyō 大正新脩大藏經. Edited by Takakusu Junjirō 高楠順次郎 et al.

Tōkyō: Taishō Issaikyō Kankōkai, 1924-1935.

TYMJ = 陶淵明集. 譯注溫洪隆. Taipei: Sanmin shuju, 2017.

X = Xu zangjing 續藏經 reprint of Dai nihon Zokuzōkyō せ新纂大日本續藏經.

\section{Secondary Sources}

Adamek, Wendi L. 2007. The Mystique of Transmission: On an Early Chan History and Its Contexts. New York: Columbia University Press.

Broughton, Jeffrey L. 1999. The Bodhidharma Anthology: The Earliest Records of Zen. Berkeley: University of California Press.

Broughton, Jeffrey L. 2004. Tsung-mi's Zen Prolegomenon: Introduction to an Exemplary Zen Canon. In The Zen Canon: Understanding the Classic Zen Texts. Edited by Steven Heine and Dale S. Wright. Oxford: Oxford University Press, pp. 11-51.

Buckelew, Kevin. 2019. Becoming Chinese Buddhas: Claims to Authority and the Making of Chan Buddhist Identity. T'oung Pao 105: 357-400. [CrossRef]

Buswell, Robert E. 1988. Ch'an Hermeneutics: A Korean View. In Buddhist Hermeneutics. Edited by Donald S. Lopez Jr. Honolulu: Hawai'i University Press, pp. 231-56.

Chen, Guying. 2016. Laozi jinzhu jinyi 老子今注今譯. Beijing: Shangwuyin shuguan.

Jonathan Christopher Cleary, trans. 1986, Zen Dawn: Early Zen Texts from Tun Huang. Boston: Shambala.

Cleary, Thomas, and Jonathan Christopher Cleary. 2005. The Blue Cliff Record. Boston: Shambala.

Davis, Albert Richard. 2009. T'ao Yüan-Ming. His Works and Their Meaning. Translation and Commentary. Cambridge: Cambridge University Press, vol. I.

Foulk, Griffith T. 1992. The Ch'an Tsung in Medieval China: School, Lineage, or What? The Pacific World, New Series 8: 18-31.

Gregory, Peter N. 1987. Sudden Enlightenment Followed by Gradual Cultivation: Tsung-mi's Analysis of Mind. In Sudden and Gradual: Approaches to Enlightenment in Chinese Thought. Edited by Peter N. Gregory. Honolulu: Hawai'i University Press, pp. 279-320.

Gregory, Peter N. 2002. Tsung-mi and the Sinification of Buddhism. Honolulu: University of Hawai'i Press.

Heine, Steven, and Dale S. Wright, eds. 2000. The Kōan: Texts and Contexts in Zen Buddhism. New York: OUP.

$\mathrm{Hu}$, Shi. 1988. Shenhui heshang yiji 神会和尚遺集. In Chanzong quanshu Vol. 36 禪宗全書 36 巻語錄部一. Taipei: Wenshu Wenhua Youxian Gongsi.

Ibuki, Atsushi. 2020. Shiji kechimyaku den no seiritsu to henka, narabi ni ta no Jinne no chosaku to no kankei ni tsuite『師資血脈傳』 の成立と變化、竝びに他の神會の著作との關係について. Tōyō shisō bunka 東洋思想文化 7-3: 116-88.

Iriya, Yoshitaka. 1968. Denshin hōyō; Enryōroku 伝心法要 — 宛陵錄. Tokyo: Chikuma shōbō.

Jia, Jinhua. 2006. The Hongzhou School of Chan Buddhism in Eighth-through Tenth-Century China. New York: State University of New York Press.

Kinugawa, Kenji. 2012. Sodōshū gohō kenkyū sadan 祖堂集語法研究瑣談. Hanazono daigaku bungakubu kenkyū kiyō 花園大学文学部研 究紀要 44: 31-58.

Lai, Whalen, and Lewis R. Lancaster, eds. 1983. Early Ch'an in China and Tibet. Berkeley: Asian Humanities Press.

Mano, Shōjun. 1964. Bukkyō ni okeru shū kannen no seiritsu 仏教における宗観念の成立. Kyoto: Risōsha.

Mazanec, Thomas J. 2017. The Medieval Chinese Gāthā and Its Relationship to Poetry. T'oung Pao 103: 94-154. [CrossRef]

McRae, John. 1986. The Northern School and the Formation of Early Ch'an Buddhism. Honolulu: University of Hawai'i Press.

McRae, John. 1987. Shen-hui and the Teaching of Sudden Enlightenment in Early Ch'an Buddhism. In Sudden and Gradual: Approaches to Enlightenment in Chinese Thought. Edited by Peter N. Gregory. Honolulu: Hawai'i University Press, pp. 227-75. 
McRae, John. 2003. Seeing through Zen: Encounter, Transformation, and Genealogy in Chinese Chan Buddhism. Berkeley and Los Angeles: University of California Press.

McRae, John. 2005. Essentials of the Transmission of Mind. In Zen Texts. Berkeley: BDK and Numata Center for Buddhist Translation and Research, pp. 1-45.

John Minford, trans. 2019, Tao Te Ching: The Essential Translation of the Ancient Chinese Book of the Tao. London: Penguin Books.

Mun, Chanjun. 2006. The History of Doctrinal Classification in Chinese Buddhism. Lanham: University Press of America.

Ogawa, Takashi. 2007. Jinne: Tonkōbunken to shoki no zenshūshi 神会: 敦煌文献と初期の禅宗史. Kyoto: Rinkawa Shoten.

Poceski, Mario. 2007. Ordinary Mind as the Way: The Hongzhou School and the Growth of Chan Buddhism. New York: Oxford University Press.

Robson, James. 2008. Signs of Power: Talismanic Writing in Chinese Buddhism. History of Religions 48: 130-69. [CrossRef]

Schlütter, Morten. 2007. Transmission and Enlightenment in Chan Buddhism Seen Through the Platform Sūtra (Liuzu tanjing 六祖壇 經). Chung-Hwa Buddhist Journal 20: 379-410.

Schlütter, Morten. 2008. How Zen Became Zen: The Dispute Over Enlightenment and the Formation of Chan Buddhism in Song-Dynasty China. Honolulu: Hawai'i University Press.

Sharf, Robert H. 2002. Coming to Terms with Chinese Buddhism: A Reading of the Treasure Store Treatise. Honolulu: Hawai'i University Press.

Tang, Yongtong. 1963. Zhongguo fojiao zongpai wenti bulun 中國佛教宗派問題補論. Beijing Daxue Xuebao 北京大學學報 5: 1-18.

Hakuju Ui, trans. 1992, Denshin hōyō 伝心法要. Tokyo: Iwanami.

Weinstein, Stanley. 1987. Schools of Buddhism: Chinese Buddhism. In Encyclopedia of Religion. Edited by Mircea Eliade. New York: Macmillan, vol. 2, pp. 482-87.

Welter, Albert. 2000. Mahakasyapa's Smile: Silent Transmission and the Kung-an (Kōan) Tradition. In The Kōan: Texts and Contexts in Zen Buddhism. Edited by Steven Heine and Dale S. Wright. New York: OUP, pp. 75-109.

Welter, Albert. 2004. Lineage. In Encyclopedia of Buddhism. Edited by Robert E. Buswell Jr. New York: Macmillan, pp. 461-65.

Welter, Albert. 2006. Monks, Rulers, and Literati: The Political Ascendancy of Chan Buddhism. New York: Oxford University Press.

Wright, Dale S. 1998. Philosophical Meditations on Zen Buddhism. Cambridge: Cambridge University Press.

Wright, Dale S. 2004. The Huang-po Literature. In The Zen Canon: Understanding the Classic Zen Texts. Edited by Steven Heine and Dale S. Wright. Oxford: Oxford University Press, pp. 107-35.

Yampolsky, Philip B. 1967. The Platform Sutra of the Sixth Patriarch. New York: Columbia University Press.

Yanagida, Seizan, and Kōyû Shiina, eds. 2001. Zengaku tenseki gyōkan: Bekkan 禅学典籍業刊: 別巻. Kyoto: Rinkawa Shoten.

Yanagida, Seizan. 1971. Shoki no zenshi I 初期の禅史 I. Tokyo: Chikuma shōbō.

Yanagida, Seizan. 1983. The Li-tai Fa-pao Chi and the Ch'an Doctrine of Sudden Awakening. In Early Ch'an in China and Tibet. Translated by Carl Bielefeldt. Edited by Whalen Lai and Lewis R. Lancaster. Berkeley: Asian Humanities Press, pp. $13-49$. 